\title{
Management Wisdom of the West
}

\author{
Milan ZELENY \\ Graduate School of Business Administration, Fordham Univer- \\ sity, New York City
}

American managers have become too accustomed to the media and training gurus propagated fallacy that so called Japanese-style of management is culturally different, eastern in its outlook and collectivistic in nature: it is therefore somehow 'unamerican' and somewhat difficult to transfer or adopt.

Such conclusions are not only incorrect, but reflect a deep-seated lack of historical awareness and alarmingly limited knowledge of our own Western management traditions. The role of teachings of Deming and Juran in forming the Japanesestyle management is now well known. Less well known are the actual American, European and Australian management practices, extending from the early twenties until this very day, which not only constitute the very foundations of today's Japanese-style management, but surpass it in breadth, potential and proven practice.

In other words, there is no fundamentally Japanese-style or American or whatever management: there is only a good or bad management, more or less suitable or fitting to a particular stage and area of global business ecology.

Rather than rediscovering, redescribing and reanalyzing some of these exquisite management systems, we have compiled typical quotations, slogans or wisdoms which are strikingly and undoubtedly Western, American, capitalistic and individualistic in all their respects. We call this proud compilation 'Management Wisdom of the West' and offer it, equally proudly, to the young managers and business students of our global village.

IOS Press

Human Systems Management 9 (1990) 119-125
Henry Ford. Mostly from his book Today and Tomorrow, Doubleday, Page \& Company, Garden City, NY, 1926; reprinted by Productivity Press, Cambridge; MA, 1988.

If you shovelled a building full of dollars, you would not have the same capacity for production and use as you would have if you filled the same building with machinery and organization of human skill.

Money put into business as a lien on its assets is dead money. When industry operates wholly by the permission of 'dead' money, its main purpose becomes the production of payments for the owners of that money. If quality of goods jeopardizes these payments, then the quality is cut down. If full service cuts into the payments, then service is cut down. This kind of money does not serve business. It seeks to make business serve it.

Live money in a business is usually accompanied by the active labour of the man or men who put it there. Dead money is a sucker-plant.

Another rock on which business breaks is debt. Debt is nowadays an industry. Luring people into debt is an industry. Possibly it is true that many people, if not most, would bestir themselves very little were it not for the pressure of debt obligations. If so, they are not free men and will not work from free motives. The debt motive is, basically, a slave motive.

Business that exists to feed profits to people who are not engaged in it, stands on a false basis. This is being so well understood that it has become a part of the creed of commerce that the service of business is wholly to the public and that the profits of business are due, first to the business itself as a serviceable instrument of humanity, and then to the people whose labour and contributions of energy make the business going concern.

The record of financiers in business affairs is full of disaster. If finance had the far-flung power that alarmists say it has, America, like Europe, would be filled with ragged peasants (Written in 1926).

To hold up prices is to tax the people more heavily than even a government could. Good management pays dividends in good wages, lower prices, and more business; it is very bad management that can see in a revival of na- 
tional ambition only an opportunity to lay heavier burdens on the spirit of enterprise.

Labour is not a commodity. One's own workers ought to be one's own best customers.

In real business there is no gambling. Real business creates its own customer.

All of our new operations are always directed by men who have had no previous knowledge of the subject and therefore have not had a chance to get on really familiar terms with the impossible. Our invariable reply to 'it can't be done' is, 'Go do it.'

Dies are set in the anvils and hammer-faces. As in the case of upsetting machines, each hammer is set with dies that enable it to perform a complete phase of the work of manufacture. There is no division of labor between hammers.

We will use material more carefully if we think of it as labour. We will not so lightly waste material simply because we can reclaim it - for salvage involves labour. The ideal is to have nothing to salvage.

Having on hand twice as much material as is needed which is only another way of saying twice as much stored human labour is needed - is precisely the same as hiring two men to do the job that one man ought to do. Hiring two men to do the job of one is a crime against society.

Our finished inventory is all in transit. So is most of our raw material inventory.

One cannot hope to live on a community - one must live in a community.

The function of the machine is to liberate man from brute burdens, and release his energies to the building of his intellectual and spirtual powers for conquests in the field of thought and higher action. One has only to go to other lands to see that the only slave left on Earth is man minus machine.

The stock market as such has nothing to do with business. It has nothing to do with the quality of the article which is manufactured, nothing to do with the output, nothing to do with the marketing, it does not even increase or decrease the amount of capital used in the business. It is just a little show on the side.

If not a single share of stock were to change hands, it would make no difference to American business. And if every share of stock changed hands tomorrow, industry would not have a cent more or cent less of capital to work with. The whole stock activity, therefore, is on par with organized baseball ...

The absentee stockholder is one of the principal, though concealed, items in the unnecessary and preventable costs of living.

Industry is not money - it is made up of ideas, labour and management, and the natural expression of these is not dividends, but utility, quality, and availability. Money is not the source of any of these qualities, though these qualities are the most frequent sources of money.

One of the great steps which the United States might take would be to wipe out all tariffs on imports. That would be a real contribution to the world, and also it would be a real contribution to American industry.

Ross Perot. Mostly from his February 15, 1988 article in Fortune, 'How I Would Turn Around GM.'

Financial people will be responsible for maintaining accounting information. People who know how to build cars and serve customers will make the product decisions. Accountants will not sap the productivity of car builders with guerrilla warfare.

(I do not know a company that like accountants. They usually come with numbers that show that something won't work ... Roger Smith, replying to Ross Perot)

Starting today, GMers are going to work together, using brains, wits, creative abilities and initiative as substitutes for money. GM will use money like a scalpel not a bulldozer. The serious problems facing GM have little to do with capital expenditures and everything to do with tapping the full potential of the GM team. If spending money were the answer, GM would already be the first and best at everything it does.

Listen, listen, listen to the customers and the people who are actually doing the work.

Customer problems will not be looked upon as legal problems but as service problems that must be solved immediately. From now on, the customer is king!

Eliminate all waste, starting at the top. Huge staffs, now in place, act as buffers shielding the people running the company from reality. These staffs will be abolished, opening up lines of communication.

Starting today, words like 'management,' 'labor,' 'bonus-eligible,' 'salaried,' and 'hourly' will no longer be used. From this day forward, everyone is a GMer. Everyone will be a full member of a closely knit, unified GM team.

As of today, all people who manage in an authoritarian way will be fired. First feed the troops, then the officers.

The primary financial incentive offered will be GM 
stock. There is only one way to make the stock go up: Be the best.

We've got to nuke the GM system. We've got to throw away Sloan's book [My Years With General Motors, former chairman Alfred P. Sloan Jr.'s description of GM's management system]. It's like the Old Testament - frozen thousands of years ago.

I come from an environment where, if you see a snake, you kill it. At GM, if you see a snake, the first thing you do is go hire a consultant on snakes. Then you get a committee on snakes, and then you discuss it for a couple of years. The most likely course of action is - nothing. We need to build an environment where the first guy who sees the snake kills it.

I'd get rid of the symbolic things that separate people. I took the position that anybody who needed a chauffeur to drive him to work was probably too old to be on the payroll.

George F. Johnson. Mostly from William Inglis's book George F. Johnson and His Industrial Democracy.

The trouble with most employers is that they don't see far enough ahead. If they did, if they had real vision, they'd see that they would be better off paying good wages and helping their workers to lead normal, happy lives, owning their homes and being a real part of the community. But the short-sighted employers want to make quick money, and think they can get it by paying as little as possible, exploiting their workers and the people who buy their product.

We could build up a great enterprise by making our workers comfortable, free of worry, whether in the factory or in their homes; by thinking of them and treating them as human beings, not machines to be run till they broke down and had to be scrapped; to make them as contended as we could within reason. Men everywhere respond to this kind of treatment. It is decent; it is common sense - and it pays too; pays everybody in the enterprise and the whole community.

Those who control labor must live with labor. The children of the workers should grow up with the children of the employers. Executives should be familiar with the lives of their workers - not in a prying sense, but in a social sense. They should be concerned with the happiness and the prosperity of the men and their families. It isn't all-important that the owners shall prosper much, but that people dependent on industry shall prosper in reason.

Aristocracy - aristocracy of labor, of wealth - I hate it. Because others are shortsighted is no reason why should I be so. This industry is built on the ideal of democracy, of humanity - and therein lies its strength.

We have a rule that any worker or group of workers with a grievance may come at any time of the day directly to me - even in director's meeting. We keep up the human touch.

But the strongest thing in our organization is the good faith based on solid friendship and mutual regard between the head of the concern and the workers - not policy but real friendship. That is our real foundation.

All our executive positions are filled by men who began at the bottom and worked all the way up.

If you want to be 'one hundred percent American,' be considerate and tolerant, broad and liberal - God-loving and man-loving. Then you will be one hundred percent American,' even though you happened to be born in Africa. Without this, you won't be 'one hundred percent American,' even though you and your parents and grandparents and greatgrandparents were born on Bacon Hill.

There is more profit in selling millions of shoes to the multitude than in selling mere thousands to the lovers of luxury.

Every improvement we make, every improvement and every saving we effect, is divided into three parts: the workers', the consumers' and the company's. That is one of the best ways to make a business successful and keep it so. People who sell our shoes and people who wear them know from experience that we give them at a lower price the best leather and the most skillful workmanship. So long as we play fair with all three parties in the business, we can be reasonably hopeful of prosperity.

James F. Lincoln. Mostly from his book $A$ New Approach to Industrial Economics. The DevinAdair Company, New York, 1961.

The usual absentee stockholder contributes nothing to the efficiency of the operation. He buys a stock today and sells it tomorrow. He often does not even know what the company makes. Why should he be rewarded by large dividends?

There are no layoffs at the Lincoln Electric Company when business slumps. Employment is continuous. There 
is only retirement at advanced age and the occasional drop-off, when the man does not fit.

There is no doubt that following habit relieves us of much mental effort. Following habit, however, prevents progress. Progress is made only by doing the new and habitually unusual. Progress can be made in no other way.

The worker today is an expert who has abilities that are far beyond the boss's. His contribution is completely necessary if industry is to succeed and progress.

Since the wish to make the product better in design and lower in cost is the desire of all involved, there will be continuous development of the latent abilities of all those who are responsible for this progress in the company. They will as a consequence be progressively more able, more productive and more efficient. They will constantly increase in individual stature.

The worker will be continuously employed. This will eliminate his fear of the future, which now makes him resist progress in efficiency.

The interests of labor, management and the customer are identical in the final analysis. They are the same people ultimately.

Only management is responsible for the loss of the worker's job. Only management can follow and develop a program that will bring in orders. The worker can't. Management, which is responsible, keeps its job. The man who had no responsibility is thrown out. Management failed in its job and had no punishment. No man will go along with such injustice, nor should he.

There are two groups who must be rewarded by increased profits. They are, first, the workers, from top to bottom, who increased the profit by their skill and cooperation. Second, of equal importance, is the customer. He paid for all the costs of production and all profit. He is the reason that industry exists.

The last group to be considered is the stockholders who own stock because they think it will be more profitable than investing money in any other way.

The stockholder, as listed here, is not the man who is the owner or who founded the business or supplied the original capital. Such founding owners usually are actual producers and should be so considered. But the absentee stockholder is not of any value to the customer or the worker, since he has no knowledge of nor interest in the company other than greater dividends and an advance in the price of his stock.

Cooperation between labor and management must be accomplished if we are to retain our present position in the family of nations. We are rapidly losing our place now in competition with manufacturers in Europe and Asia. If this continues as it is now going, we soon will be outdistanced.

With our present program of collective bargaining, management and labor together determine how much the customer will pay for the worker's remuneration and for his inefficiencies. The customer, who pays all costs, is not even consulted. It is not strange that the results from such irresponsible bargaining should be disappointing and often foolish, as we now see.

The proper responsibility of industry is to build a better and better product at a lower and lower price.

There is no known limit to the cost reductions that can be made in the manufacture of any product if cost reduction is the actual goal of both management and men. But that goal is largely changed to profits and dividends when the hired manager is under the direction of the stockholder.

As the rare geniuses that are in the industry disappear, the economy will be greatly changed by their absence. The individual owner and operator of an industry has an entirely different outlook and goal for his company than the hired managers who operate the large and complex organizations, which are the results of the present combinations of smaller companies that have been absorbed.

Industry's goal, if it is to succeed as it can, must be completely different from simply increasing dividends. Industry controls our standard of living. We cannot allow it to be converted to a source of profit only for a limited number of non-producing people.

Salesmen will change from peddlers to consultants. Their number will greatly decrease. Advertising will be changed from deception to instruction and it will also decrease in volume. The reputation of a product will be determined not by the quantity of money spent in advertising it, but by its actual use to the customer.

The goal of properly led company is better quality at a lower price. If it does not or cannot do that, it should disappear and eventually it will. Competition will destroy it in a free market. That is what competition is for.

Efficiency cannot eliminate jobs because increased efficiency lowers costs, lower costs cause lower prices, lower prices expand the market, and an expanding market increases employment.

It is no part of management's responsibility to be merely kind to workers. Managers are responsible for efficien- 
cy in their industry. Efficiency depends on human cooperation within the industry. If genuine cooperation is to be regained, it is absolutely essential that wageearner's present fear of losing his income be eliminated. That fear can be eliminated only by removing the danger. This can be done only by guaranteeing continuous employment.

It is strange that people suppose that men are more careful of other men's property than of their own. In fact, government operation always has been far more wasteful than private enterprise.

Sir Fletcher Jones. Mostly from his book Not by myself, Kingfisher Books Pty Ltd., Cheltenham, Vic., 1976.

Customer benefits come first, second and third.

Quality without compromise.

Management by Consultation.

Family \& Staff Co-operative Ownership.

The retail salesman acted both as buying agent for his customer and as the last element in a production line which began with the cloth developers and ended 'two feet from the customer.'

Employee shares carry equal rights and all shares remain within the FJ Family. Any shareholder who left the employ before retiring age was expected to sell his or her shares. Shares held by present and past employees, and the widows of deceased employees now exceed 70 per cent. Our shares should not be looked on as means of speculation. Each year in addition to our normal cash dividend, a dividend of 5 per cent to 7 per cent has been satisfied by the allotment of shares.

The only justification for the ownership of the means of production and distribution lies in a determination to 'give more and more for less and less.'

Fletcher Jones will remain interested in your garment as long as you are.

If you need to buy sixty dozen items it is better to buy them from two selected suppliers than from ten. A buing order is like a small piece of butter. A small piece of butter spread over many pieces of bread just cannot be tasted.

The retailer is the customer's buying agent. In Group Buying one details the customer's needs and plans to have the right garment in the right place at the right time and at the right price.

Any fool can buy successfully as long as he continually asks himself two important questions. They are 'Where is the need?' and 'Whom shall we serve?'

It All Depends on Me.

Let the People Sing.

Use your head when buying a hat.

Look at your hat - Everyone else does.

No Man is Hard to Fit.

No Credit for Anyone.

We've had shops with no offices and desks in odd places. We've insisted on a cash-only policy for all customers. We've been obsessed with making sure our garments fit. We've stuck to a monetary mark-up system or pricing. We've hoped in all our ways to give more and more for less and less.

No man should leave the world as bad as he found it.

What a man says whispers - what he does thunders.

Correct fitting is three dimensional. You have to fit a man's mind as well as his body. Then, when you think you've managed this, you find you have to fit his wife's mind as well.

If you are an industrialist who is interested in people you are more likely be interested in decentralization than you would be if you were interested in profits or in personal convenience.

If it is good for one man to concentrate on a current problem, why not get a lot of men concentrating on the same well-defined problem and doing so in one spot altogether? We have found the stand-up meeting to be a good way of doing this.

KISS: Keep It Simple, Stupid.

A man needs more satisfaction from his work. The pay envelope is important. Of course it is. But jobsatisfaction is more vital. One of the tragedies of to socalled economics of scale in this modern world of ours is the way in which the importance of the individual seems to have become of decreasing significance.

'Lord, if Though dost allow me to have a shop some day, I promise Thee that I will run it from the customer's point of view.'

We are going to build a new kind of factory. We will pull all these rules down from the walls: Thou shalt not this, thou shalt not that, thou shall this and that.

We will put up the only rule that matters, Do unto others as ye would be done by.

John Wanamaker

No war, no strike, no depression can so 
completely destroy an established business, or its usefulness, as new and better methods, equipment and materials, in the hands of an enlightened competitor.

The never ending quest for better quality can surely be a good substitute for the individual's pride in craftsmanship of days gone by. A continuing interest in the customer's property can be a substitute for the personal relationships which might have existed between the craftsman and his customer.

Tomáš Bat'a. Mostly from his book Úvahy a proje$v y$ (Reflections and Speeches), TISK, Zlín, 1932. Reprinted by SÚTB, New York, 1986. Also from A. Cekota's Entrepreneur Extraordinary, Edizioni Internazionali Sociali, Rome, 1968.

The only thing we can never consider to be our private property is our life - we contributed nothing to its origin. It was loaned to us with the duty to pass it on to our descendants improved and enriched.

To make capitalists from all of our employees is one of the primary objectives of my business.

Our customer - our master.

Buildings - they are just piles of brick and concrete. Machines - they are a lot of iron and steel. Only people can give life to it all.

I have no wealth - I have only shoes for customers and leather for workers. It is the same kind of wealth as telescope is for an astronomer or violin for a musician. Without it, I could not give work to my associates and shoes to my customers. I would be of the same value to the world as a violinist without a violin.

We are offering you to share in profits not because we have a need to distribute money among people out of charity. It should help us to further lower our production costs and enable workers to earn more while manufacturing cheaper shoes.

Do not fear that increased work efficiency would make you lose your job. Our goal is to produce ten times more than at present. Until now we were prevented to achieve this because we lacked clever, dedicated people ready to manage the new departments. By profit sharing we intend to boost the morale and material well-being of the workers. We wish that all our workers become financial partners in our enterprise.

The profit sharing of employees is obviously not a new idea. At the present time, it is used the most by the Ameri- can entrepreneurs. I was, however, looking for a way of employees' profit sharing which would help to establish an autonomy of the workshop.

The workshop autonomy is not only cheaper but also better. Nobody knows the job impediments better than I do, actually performing the work. The better the selection of the workshop participants and the smaller their turnover, the more successful will the autonomy be.

A competent executive is busy running around, searching for and educating people who could replace him and eventually take over his job altogether.

A business managed according to our principles is undefeatable even against the strongest competition. For my work I do not need support from anybody, especially not from the State. Only one thing is necessary: to be allowed to work freely.

An industrial enterprise is to its employees the same source of livelihood as land is to farmers. Public welfare, today and in the future, depends on how much profits are ploughed back into the enterprise.

Our company cafeteria is causing us headaches: it is being badly managed. Therefore, I and all directors have decided to take all our meals there on a daily basis.

We cannot absolve ourselves from helping people through compassion and gifts. But our duty is to teach them how to rely on themselves so that they can help themselves.

You will see, Mr. President, that every one of us, each employee, has an electrical robot at his disposal. I consider it one of my greatest achievements that these robots now perform the work which used to leave bloody blisters on hands of our fathers. Robots release the greatest powers of man - the powers of human mind.

Americanism is an empty word. No '-ism' has ever helped anybody or resolved anything. And it never will.

High wages are achievable only through human intelligence.

Those who are chasing after the money will never catch them. Concentrate on your work and do it better than your neighbor. Money will then chase after you - willingly and voluntarily.

Repayment of debts is the best investment.

As of September 1, we are cutting average prices in half, so as to:

make possible for the population to buy their fall footwear;

keep production going;

prevent laying off workers; 
save the state paying unemployment insurance; initiate overall price declines;

help overcome the economic recessions; and make us more competitive in world markets.

To make this possible we are reducing production costs, including 40 per cent reduction in wages. To compensate workers for part of the loss in purchasing power, we guarantee to lower their prices of basic consumer goods by 50 per cent under the levels prevailing last May.

We shall achieve real success only when we educate the people to manage and direct their own work. It is more difficult to teach people to think for themselves than to obey.

We know what our sales department would look like, with its many branches and stores, if we had not discovered the way to turn our store managers into entrepreneurs. These branches and stores enjoy complete autonomy.

A great number of property-owning employees with economic self-discipline will bring to our enterprise an undreamed-of expansion. What is lacking in these people, who would otherwise possess all the necessary qualities, is the ability to manage their own financial affairs. The company must serve first as a worthy example of the good businessman.

Our enterprise is already directing itself to these principles. We have the financial ability to pay out at any time the claims of the employees. We do not utilize bank loans and credit. We pay our suppliers cash, immediately upon receipt of the goods. The money we owe to our employees is deposited in safe bonds, readily transferrable into cash. We do not use the employees' savings for the operation of the business.
Homer M. Sarasohn. Mostly from his and Charles Protzman's 1948 book CCS: Industrial Management and the February 6, 1989 article in Forbes, pp. 70-78.

Managers should look at every aspect of a manufacturing operation as a piece of an integrated system, and should think through the consequences for the entire system of fiddling with any of its parts.

Every company needs a concise, complete statement of the purpose of the company's existence, one that provides a well-defined target for the idealistic efforts of the employees.

Companies must put quality ahead of profit, pursuing it rigorously with techniques such as statistical quality control.

Every employee deserves the same kind of respect fellow managers receive, and good management is 'democratic management.' Lower-level employees need to be listened to by their bosses.

We shall build good ships here; at a profit if we can, at a loss if we must, but always good ships.

Motto of Newport News Shipbuilding

Every business enterprise should have as its very basic policy to aim the entire resources and efforts of the company toward a well-defined target, a target that would benefit society.

This present-day fad of aping the Japanese style of management is absolutely destructive of our own future. We've got to recapture the enthusiasm, the pioneering spirit that made America a world leader. 